\title{
THE
}

MATHEMATICAL

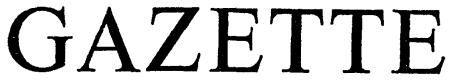

EDITED FOR THE MATHEMATICAL ASSOCIATION BY

R. L. GOODSTEIN

WITH THE ASSISTANCE OF

H. M. CUNDY K. M. SOWDEN

MAY 1957

Vol. XLI No. 336

Equilibrium of Sets of Particles on a Sphere. J. Leech

page 81

Forms and Functions. H. Perfect

Geodesic Opposites on a Regular Tetrahedron. H. G. ApSimon 95

Solving Quadratics Quickly. R. F. Wheeler $\quad 98$

Problem. D. J. Behrens 101

The Cissoid of Diocles. J. P McCarthy 102

Motion in a Horizontal Circle. J. G. Freeman 105

A Net to Hold a Sphere. A. S. Besicovitch 106

Some Calculations in Logic. C. C. H. Barker 108

Correspondence 112

Mathematical Notes (2677-2702). H. G. ApSimon ; A. Buckley ; W. A. Capstick ; A. J. Carr ; T. M. Flett ; R. L. Goodstein ; R. Goormaghtigh ; J. A. K. Kashangaki ; F. R. Keogh ; B. V. Landau ; A. J. Moakes ; A. N. Nicholson ; R. V. Parker ; G. M. Petersen ; E. J. F. Primrose ; A. K. Rajagopal ; M. N. Rajalakshamma ; M. Rumney ; M. Sankaran ; L. M. Milne-Thompson ; R. F. Wheeler ; N. Y. Wilson.

Pseudaria

Reviews. T. A. A. Broadbent ; J. W. Colley ; F. Conway ; J. L. B. Cooper ; J. C. W. De La Bere ; J. K. Dudley ; A Fletcher ; F. G. Friedlander ; R. O. Gandy ; R. L. Goodstein ; W. K. Hayman ; J. W. Hesselgreaves ; P. J. Hilton ; W. Ledermann ; L. Mirsky ; E. J. F. Primrose ; D. E. Rutherford.

Gleanings Far and Near (1877-1883)

Address of the Mathematical Association and of the Hon. Treasurer and Secretaries 


\section{ELEMENTARY MECHANICS}

by D. A. QUADLING, M.A., Senior Mathematics Master, Marlborough College, and A. R. D. RAMSAY, M.A., Christ's College, Christchurch, New Zealand, formerly Senior Mathematics Master, Marlborough College. Volume I ready Autumn 1957.

In this first-year book, for students beginning mechanics, the subject is approached through practical problems, but from the start the emphasis is on a clear understanding of the principles on which it is based. Dynamics and statics are treated together; the order of topics selected by the authors is flexible, however, and could be varied by the individual teacher using the book. It will be found that the course covers the work of the Ordinary level G.C.E. examination in mechanics and additional mathematics of all examining bodies.

There is a very large number of carefully graded examples to be worked by the student. In addition to the examples associated with each chapter there are four exercises containing in all 200 miscellaneous questions, taken mostly from examination papers.

The book is designed as the first part of a three-part course, and a second-year book is in active preparation covering the requirements of G.C.E. Advanced level, the Qualifying Examination for the Mechanical Sciences Tripos, and B.Sc. (Engineering) Part I. The third volume will cover more advanced mechanics.

\section{CLASSBOOK OF ARITHMETIC AND TRIGONOMETRY}

by S. F. TRUSTRAM, M.Sc., Principal, Salisbury and South Wilts College of Further Education, and $\mathrm{H}$. WHITTLESTONE, B.Sc., Senior Mathematics Master, Grammar School, Normanton. Part I ready Autumn 1957.

A Classbook of Arithmetic and Trigonometry follows the lines of $A$ Classbook of Algebra, by S. F. Trustram, now in its 8th edition. The authors adopt the principle that a textbook should be a teaching aid and not a course of instruction ; consequently the book consists mainly of examples. These are carefully graded and each new development is preceded by leading questions wherein the fresh topic is analysed so that progress may be based upon previous knowledge. Adequate attention is given to drill in fundamental processes, and a special feature of the book is the wealth of examples provided to overcome the routine difficulties which so often render fresh advances unnecessarily difficult.

The book will be issued complete and in two parts. The complete edition will cover fully the arithmetical topics and trigonometry required for the G.C.E. Ordinary level papers of the various examining boards. 